\title{
On the fringe of COVID-19: our experience in Joseph Hospitals
}

\author{
Vasanthi Balamurugan*, Kurian Joseph, Rekha Kurian, Tarun Joseph
}

Department of Obstetrics and Gynecology, Joseph hospitals, Chennai, Tamil Nadu, India

Received: 13 September 2020

Accepted: 29 October 2020

\section{*Correspondence:}

Dr. Vasanthi Balamurugan,

E-mail: vasanthivaradhan@yahoo.co.in

Copyright: (C) the author(s), publisher and licensee Medip Academy. This is an open-access article distributed under the terms of the Creative Commons Attribution Non-Commercial License, which permits unrestricted non-commercial use, distribution, and reproduction in any medium, provided the original work is properly cited.

\begin{abstract}
Background: The coronavirus pandemic is an ongoing pandemic of coronavirus disease 2019 (COVID-19) caused by severe acute respiratory syndrome coronavirus 2 (SARS-CoV-2). There is no evidence that pregnant women are more likely to get seriously ill from coronavirus but pregnant women have been included in the list of people at moderate risk (clinically vulnerable) as a precaution. The aim of the study was to determine the incidence of COVID positive cases and its management.

Methods: This is a prospective observational study done in the Department of OBGYN, Joseph hospitals, Chennai, Tamil Nadu over a period of 4 months (April-July 2020).

Results: Over the month of April and May, among the tested population none had positive result. But in the month of June and July, we had $6.3 \%$ and $8.2 \%$ of patients tested positive among the population due to universal screening.

Conclusions: This study highlights the difficulty in small hospitals to allocate the resources, handle the patient and importantly protect the staff. These are difficult times and the private hospitals must come forward to help the government set up in handling the cases on "the fringe of COVID".
\end{abstract}

Keywords: Coronavirus, Pandemic, Clinically vulnerable

\section{INTRODUCTION}

The coronavirus pandemic is an ongoing pandemic of coronavirus disease 2019 (COVID-19) caused by severe acute respiratory syndrome coronavirus 2 (SARS-CoV$2) .{ }^{1}$ It is a respiratory virus spreads primarily through droplets generated when an infected person coughs or sneezes or through droplet of saliva or discharge from nose. ${ }^{2}$ "There is no evidence that pregnant women are more likely to get seriously ill from coronavirus but pregnant women have been included in the list of people at moderate risk (clinically vulnerable) as a precaution". 3

Pregnant women should follow latest guidance on staying safe and alert and avoiding people who has symptoms suggestive of corona virus. Women should keep ambulating and be hydrated to reduce the risk of thrombosis in pregnancy. They are advised to stay active with regular exercise, a healthy balanced diet, folic acid and vitamin D supplementation to help support healthy pregnancy. ${ }^{4}$ Though flu vaccination in pregnancy does not protect from exposure to COVID-19, it is better to take it on time in pregnancy because it makes less susceptible to influenza which can cause complications in pregnancy.

"There is no evidence to suggest an increased risk of miscarriage if infected with COVID-19 and are pregnant. Emerging evidence suggests that transmission from women to her baby during pregnancy or birth is probable". It is important to emphasize that most of the reported cases of term babies born to COVID-19 positive mothers test negative and even if positive, babies are doing well. Across the world, emerging reports suggests some babies have been born prematurely to women who were very unwell with COVID. "It is unclear whether coronavirus caused these premature births or whether it was recommended that 
their babies were born early for the benefit of women's health and to enable them to recover". 5

\section{METHODS}

This was a prospective observational study done in the Department of Obstetrics and Gynecology, Joseph hospitals, Chennai, Tamil Nadu over a period of 4 months (April-July 2020). The hospital is catering to its obstetric patients but was not a COVID treatment centre. Hence, we had to take extreme care whenever a patient came in to determine if she was COVID positive and treat. All positive patients had to be shifted to COVID care centres. Further being a private centre all expenses were borne directly by the patients. This led to several adjustments being made in handling the patients, the protocols and most importantly keep the costs under control.

When the patient enters the hospital, temperature was checked both for the patient and attender by thermal scanner at the time of admission. Initially during the period of April and May 2020, only patients coming from containment zone and patients exposed to carriers were tested for COVID-19 (reverse transcription-polymerase chain reaction (RT-PCR), Throat swab). Later, all antenatal patients were screened universally five days before their expected delivery date. Few unscreened patients who came in active labour were admitted in isolation ward, throat swab was taken after admission and delivered in separate labour rooms allocated for those patients. Patient whose report came as positive for COVID-19 were referred to designated COVID centres for further management.

\section{RESULTS}

In our study, we did a prospective analysis of delivery statistics of four months (April 2020 to July 2020) in our institution. The total number of deliveries each month ranging from 98-110. Among which total vaginal deliveries on an average was 76-83\% and lower segment caesarean section (LSCS) were $17-25 \%$ as mentioned in table 1. Table 2 indicates total number of patient tested positive for COVID-19 during the study period. In the later period of study, due to universal screening, we had $6.3 \%$ and $8.2 \%$ of the population tested positive in the month of June and July 2020. Once the patients report comes as positive, we had referred those patients to the designated COVID centres depending on their socio-economic status. The details of patients being referred and their follow up is been mentioned in table 3 .

Table 1: Total number of deliveries and mode of delivery.

\begin{tabular}{|lllll|}
\hline $\begin{array}{l}\text { Month/ } \\
\text { mode of } \\
\text { delivery }\end{array}$ & $\begin{array}{l}\text { April } \\
\mathbf{2 0 2 0}\end{array}$ & $\begin{array}{l}\text { May } \\
\mathbf{2 0 2 0}\end{array}$ & $\begin{array}{l}\text { June } \\
\mathbf{2 0 2 0}\end{array}$ & $\begin{array}{l}\text { July } \\
\mathbf{2 0 2 0}\end{array}$ \\
$\begin{array}{l}\text { Total } \\
\text { deliveries }\end{array}$ & 98 & 103 & 110 & 109 \\
\hline $\begin{array}{l}\text { Vaginal } \\
\text { deliveries }\end{array}$ & 81 & 78 & 84 & 86 \\
\hline LSCS & $\begin{array}{l}(83 \%) \\
(17 \%)\end{array}$ & $\begin{array}{l}(76 \%) \\
(25 \%)\end{array}$ & $\begin{array}{l}(77 \%) \\
(23 \%)\end{array}$ & $\begin{array}{l}(79 \%) \\
(21 \%)\end{array}$ \\
\hline
\end{tabular}

Table 2: Number of patients tested and status.

\begin{tabular}{|lllll|}
\hline Month & April 2020 & May 2020 & June 2020 & July 2020 \\
\hline $\begin{array}{l}\text { Total number of patients } \\
\text { tested for COVID-19 }\end{array}$ & $42(43 \%)$ & $99(96 \%)$ & $110(100 \%)$ & $109(100 \%)$ \\
\hline Tested before delivery & 37 & 95 & 104 & 99 \\
\hline Tested after delivery & 5 & 4 & 6 & 10 \\
\hline Total positive cases & - & - & $\begin{array}{l}7(6.3 \%)(6 \text { antenatal, } 1 \\
\text { postnatal) }\end{array}$ & $\begin{array}{l}9(8.2 \%)(4 \text { postnatal, } 4 \\
\text { antenatal, 1 termination) }\end{array}$ \\
\hline
\end{tabular}

Table 3: Details regarding referred COVID positive patient.

\begin{tabular}{|c|c|c|c|c|}
\hline Gravida/gestational age & $\begin{array}{l}\text { Referral } \\
\text { hospital }\end{array}$ & Mode of delivery & $\begin{array}{l}\text { Patients } \\
\text { symptoms }\end{array}$ & Baby's test report \\
\hline G1/39+1 weeks & Apollo & LSCS & Nil & Negative \\
\hline G2P1L1/38 weeks & SIMS & Rpt LSCS with ST & Nil & Negative \\
\hline G1/39+3 weeks & KMC & LSCS & Nil & Negative \\
\hline G2P1L1/39+4 weeks & Chettinad & Normal delivery & Nil & Negative \\
\hline G1/39+6 weeks & Gunasekharan & LSCS & Nil & Negative \\
\hline G1/36+2 weeks & Apollo & LSCS & Nil & Negative \\
\hline P2L2/Post-op POD 1 & $\begin{array}{l}\text { Thiruvallur } \\
\text { GH }\end{array}$ & LSCS & Nil & Negative \\
\hline P1L1/ PND 0 & MGM & Normal delivery & Nil & Negative \\
\hline P1L1/ PND 0 & MGM & Forceps delivery & Nil & Negative \\
\hline P2L2/ POD 1 & IOG & Rpt LSCS with ST & Nil & Negative \\
\hline
\end{tabular}

Continued. 


\begin{tabular}{|lllll|}
\hline Gravida/gestational age & $\begin{array}{l}\text { Referral } \\
\text { hospital }\end{array}$ & Mode of delivery & $\begin{array}{l}\text { Patients } \\
\text { symptoms }\end{array}$ & Baby's test report \\
\hline G1/38+2 weeks/PROM & MGM & Vacuum delivery & Nil & Negative \\
\hline G1/39+1 week & MGM & LSCS & Nil & Negative \\
\hline G1/33+3 weeks/PPROM & MGM & Normal delivery & Nil & Negative \\
\hline $\begin{array}{l}\text { P1L0A2/28+3 weeks/DCDA } \\
\text { twin/Single twin IUD }\end{array}$ & IOG & LSCS & Nil & Negative \\
\hline $\begin{array}{l}\text { G2P1L1/18+2 weeks/neural } \\
\text { tube defect }\end{array}$ & IOG & $\begin{array}{l}\text { Medical termination } \\
\text { of pregnancy }\end{array}$ & Nil & - \\
\hline $\begin{array}{l}\text { G1/38+4 weeks/LRI } \\
\text { symptoms/COVID } \\
\text { negative/CT Chest-ground } \\
\text { glass opacity }\end{array}$ & IOG & LSCS & Nil & Negative \\
\hline
\end{tabular}

\section{DISCUSSION}

In our Institution, we usually have an average of 100-120 deliveries per month. During corona pandemic also we almost had the same number of deliveries, despite lockdown in Chennai. We maintained strict protocols regarding safety measures which includes usage of hospital scrubs, hand gloves, apron, goggles, face shield, N95 masks, personal protection kits (PPE), hand sanitizers regularly before and after examining each patient, irrespective of their COVID status. During delivery, we had limited number of health care workers (3-4 people) and strict aseptic precautions were followed. Single attender only was permitted during admission who will stay till discharge. No extra visitors were allowed under any circumstances.

"Investigators reviewed center for disease control (CDC) surveillance data from January 22 to June 7, 2020, among women of reproductive age. Of 91,000 women with confirmed SARS-CoV-2 infection and known pregnancy status, $8200(9 \%)$ were pregnant". Diabetes mellitus, Chronic lung disease and cardiovascular disease were more frequent in pregnant than non-pregnant women. Compared with non-pregnant women, those with COVID, were more likely to be hospitalized, to be admitted in intensive care unit and to be intubated, and were more likely to die. ${ }^{6}$

"In a cohort study, 33 neonates born to mothers with COVID-19 in Wuhan's Childen hospital, China- out of 33, four showed symptoms of shortness of breath \& 3 tested positive for SARS-CoV-2 and all 3 were delivered by caesarean section due to maternal distress and pneumonia. All these COVID-19 neonates had fever, lethargy and pneumonia which subsided with antibiotics and proper ventilation. The nasopharyngeal and anal swabs were tested positive on day 2 and 4 but negative on day 6-7, suggesting vertical transmission from mother to neonate".

"In the recent UK study of 427 pregnant women with coronavirus published on 11 May 2020, the data reported outcomes for babies who were born to women with coronavirus severe enough that women required hospital admission. Although almost one in five were born prematurely and were admitted to a neonatal unit, fewer than 20 babies were born very prematurely (when women were less than 32 weeks pregnant)". One in 20 babies born (12 babies in total) had a positive test for coronavirus, but only half of these babies- 6 babies- had a positive test immediately after birth, suggesting that transmission of coronavirus infection from a woman to her baby is low. The number of babies born at term (37 weeks or later) to women who had tested positive for coronavirus that required neonatal care was similar to the number of babies born to women without the virus- about 1 in $10 .^{8}$

"Data from UK OSS (UK Obstetric surveillance system) study of 427 pregnant women in May 2020 found majority of women who have become severely ill from coronavirus were in third trimester, emphasizing importance of social distancing and regular hand washing from 28 weeks of pregnancy.

The study also found pregnant women from black, Asian and minority ethnic (BAME) background are more likely than other pregnant women to be admitted in hospital for coronavirus. Pregnant women $>35$ years, who are overweight or obese and those who have pre-existing medical problems like diabetes, hypertension also is at increased risk of developing severe illness".

According to statistics till 16th July 2020 in Tamil Nadu, total of 1,606 pregnant women have tested positive for COVID-19. Among which 1,104 women were discharged and the remaining are under treatment. There were zero maternal death noted. In the Institute of Obstetrics and Gynecology (IOG)- Chennai, 400 pregnant women tested positive, 374 patients were discharged. Among the newborns, 39 were tested positive which constituted 10$12 \%$ of the total. The babies were kept under observation and discharged safely without any issues.

\section{CONCLUSION}

COVID-19 in pregnancy is a complicated situation if they develop pneumonia and so a multidisciplinary team of medical experts consisting of obstetrician, infectious disease experts, anaesthetist, intensivist, paediatrician and 
psychologist are required to manage \& treat the patient. In our observation, because of less sample size and only few patients being tested positive, we could not find any correlation with COVID status and pre-existing medical condition. There were no preterm births noted, no postpartum complications. There was a high incidence of vaginal deliveries and instrumental deliveries. This is just our observation regarding initial corona times and its management. Further, large scale studies are required for more information. The aim is to make people aware that it is very important to screen pregnant women $\&$ follow strict preventive measures. If we found a COVID-19 positive, they would be quarantined, and a multidisciplinary team is needed to perform the delivery. This study highlights the difficulty in small hospitals to allocate the resources, handle the patient and importantly protect the staff. These are difficult times and the private hospitals must come forward to help the government set up in handling the cases on "the fringe of COVID"

Funding: No funding sources

Conflict of interest: None declared

Ethical approval: The study was approved by the Institutional Ethics Committee

\section{REFERENCES}

1. Xu X, Chen P, Wang J, Feng J, Zhou H, Li X. Evolution of the novel Coronavirus from the ongoing Wuhan outbreak and modeling of its spike protein for risk of human transmission. Sci China Life Sci. 2020;63(34):57-60.
2. Chan JFW, Yuan S, Kok KH, To KKW, Chu H, Yang $\mathrm{J}$ et al. A familal cluster of pneumonia associated with the 2019 novel coronavirus indicating person to person transmission: a study of a family cluster. Lancet. 2020;395(10223):514-23.

3. Siston SA, Rasmussen MA, Honein AM, Fry K, Seib WM, Callaghan. Pandemic. 2009 Influenza A (H1N1) virus illness among pregnant women in the United states. J Am Med Assoc. 2009;303(15):1517-25.

4. Yang H, Wang C, Poon LC. Novel Coronavirus infection and Pregnancy, Ultrasound. Obstet Gynaecol. 2020;55(4):435-37.

5. Sonja A, Denise J, Timothy M. Effects of influenza on pregnant women and infants. Am J Obstet Gynaecol. 2012;207(3):S3-8.

6. Wald A, Ellington S. CDC Surveillance Data suggests how pregnancy affects COVID 19's symptoms \& management. NEJM J Wat. 2020.

7. Zeng L, Xia S, Yuan W, Yan K, Xiao F, Shao J. Neonatal Early onset infection with SARS CoV 2 in 33 neonates born to mothers with COVID 19 in Wuhan, China. J Am Medic Assoc Pediatr. 2020;174(7):722-5.

8. Knight M, Bunch K, Vousden N, Morris E, Simpson $\mathrm{N}$, Gale C, et al. Characteristics and outcomes of pregnant women admitted to hospital with confirmed SARS-CoV-2 infection in UK: national populationbased cohort study. Bio Med J. 2020;369.

Cite this article as: Balamurugan V, Joseph $\mathrm{K}$, Kurian R, Joseph T. On the fringe of COVID-19: our experience in Joseph Hospitals. Int J Reprod Contracept Obstet Gynecol 2020;9:4985-8. 